12th LUMEN International Scientific Conference Rethinking Social Action. Core Values in Practice | RSACVP 2019 | 15-17 May 2019 | lasi-

Romania

\title{
The National Program „School after school"- Factual and Conceptual Premises. Educational and Legal Perspectives
}

\author{
Mirela Carmen DOBRILĂ, Bogdan Constantin NECULAU \\ https://doi.org/10.18662/lumproc.156
}

How to cite: Dobrilă, M.C., \& Neculau, B.C. (2019). The National Program „School after School”- Factual and Conceptual Premises. Educational and Legal Perspectives. In C. Ignatescu (ed.), 12th LUMEN International Scientific Conference Rethinking Social Action. Core Values in Practice, 15-17 May 2019, Iasi - Romania (pp. 82-88). Iasi, Romania: LUMEN Proceedings. https://doi.org/10.18662/lumproc.156 


\title{
The National Program „School after School”- Factual and Conceptual Premises. Educational and Legal Perspectives
}

\author{
Mirela Carmen DOBRILA ${ }^{1 *}$, Bogdan Constantin NECULAU²
}

Abstract

The School after School program must be absolutely necessary in accordance with the principle of individual and age specificities, with the particular needs and interests of the pupil, valuing his / her skills and competencies. Whether we refer to specialized support activities, to thematic ones (recreational), to sequences aimed at accelerating learning and performance or training for life, the result should focus on the harmonious development of the child child's personality. Achieving this goal would mean bringing the child / young man in a state of balance with bimself and the other, preparing to successfully meet the challenges of life and of the modern society.

The article analyzes the introduction by the Ministry of National Education of Romania of the National Program "School after school", as a new program, complementary to the compulsory school program, but different from the "After school" programs that previously functioned in the absence of a legal framework. The article highlights the educational content of the program and the legal framework for the program to run. The program's specific nature is aimed at enhancing competences, as well as elements on remedial learning, learning through educational and recreational activities, within a legal framework, with clear and express regulations.

Keywords: „School after school”; national program; educational program; legal framework.

\section{The "School after School" National Program, concept and declared purpose}

The "School after School" National Program (SDS Program) is a program designed according to the model of such programs that have been

\footnotetext{
1 Lecturer PhD, Faculty of Law, University „Alexandru Ioan Cuza” Iaşi, România, mirela.dobrila@gmail.com.

${ }^{2}$ Lecturer PhD, Faculty of Psychology and Education Sciences, University „Alexandru Ioan Cuza” Iaşi, România, bogdan.neculau@yahoo.fr. 
developed around the world in order to contribute to the development of school performance, in an organized context, with trained teachers for the pupils' needs, a program designed to help parents who want to support their children. In addition to these advantages, the "School after School" national program should also be seen in the context of efforts made to reduce the dropout rate in Romania.

According to article 58 of the Law of National Education no. 1 of 5 January 2011, the educational establishments may, by decision of the board of directors, extend their activities with pupils after classes, by programs "School after school" [1] as programs supported by the Ministry of National Education through Order no. 5349 of 7 September 2011 (OMECT 5349) [2].

The purpose stated in the Education Law of the "School after School" Program, designed as a partnership program with local public authorities and parents' associations (and if possible in partnership with nongovernmental organizations with competences in the field), is to provide educational activities, recreational, leisure time, to enhance acquired skills or accelerate learning as well as remedial learning activities. It is necessary for the program to be organized only on the basis of a methodology approved by order of the Minister of National Education.

Article 58 paragraph 4 of the Law of National Education expressly stipulates that the state has the possibility to finance the program for children and pupils from disadvantaged groups, according to the law. This provision should be read and has to be understood in close connection with the attempts to reduce the dropout rate.

The SDS program is designed by educational units as a project carried out as a result of a needs analysis (Article 3 of the methodology approved by the Ministry of National Education through Order no. 5349 of 7 September 2011/OMECT 5349 [2]) and the offer is designed to meet the needs of all pupils and prioritize the needs of pupils belonging to disadvantaged groups; thus, certain educational packages are developed, approved by the school council. The SDS program is organized by decision of the school administration board, with the approval of the school inspectorates. The idea of the SDS Program aims to find an alternative to spending leisure time in environments with the potential to develop deviant behavior (Article 2 of the methodology OMECT 5349 [2]).

\section{Content, implementation and operation of the SDS Program}

According to article 2 of the methodology approved by Order no. 5349/2011- OMECT 5349 [2], the "School after School" Program, intended 
for pupils in primary and secondary education, is complementary to the compulsory school curriculum. The SDS program aims to provide support activities to prevent school dropout and to prevent early school leaving, to increase school performance, remedial learning, to accelerate learning through educational, recreational and leisure activities, personal development and social integration, as well as maintaining students in a secure space.

SDS programs need to be correlated with strategies to prevent and reduce school dropouts, organized at school inspectorates, for example through school dropout analysis, prevention measures, conditions improvement [3], through strategies and efforts to implement measures that should prevent school dropout [4].

The SDS program is complementary to the compulsory school curriculum and is optional for the pupil; enrolment in the program is based on written request from parents, with the possibility of enrolment/withdrawal throughout the school year.

The SDS program aims to develop activities for the formation and development of competences specific to primary education or secondary education, for personal and interpersonal development/preparation for life, the harmonious development of the pupil's personality. Through its content, the program aims to empower students, skills and competences of each student in accordance with their needs and interests.

This type of program is designed to emphasize (Article 8 of the methodology) the idea of learning to study, team work, communication and relationship activities), healthy lifestyle, civic behavior.

For primary education (Article 6 of the methodology), the SDS Program includes education activities (supervision and guidance in homework, recovery for students with cognitive difficulties) that complement the teaching activity as well as support and personal development activities for students.

For secondary education (Article 7 of the methodology), SDS Program includes educational activities, complementary to didactic work (support for homework and remedial activities), correlated with supporting and personal development activities of pupils (ie. psycho-pedagogical assistance for recovery learning disparities, psychological counselling, career counseling, accelerating learning and performance, lifelong learning activities, thematic activities, workshops and others).

In its original form, the methodology provided in Article 9 a limit of 12 pupils, but this limitation is no longer regulated in its current form. The SDS program has an average duration of 3 hours per day, but not less than 12 hours per week (Article 5 paragraph 1, and Article 8 paragraph 2, of the methodology). 


\section{Resources needed to implement the SDS Program}

SDS programs are coordinated by teachers in the school where they are organized or external staff, under the supervision of teachers. According to art. 13 of the methodology, the activities may be coordinated by educational staff (ie by teachers in the school where the program is organized or other educational establishments, children's palaces and clubs for children and sports clubs, etc.) or members of community (parents, representatives of local authorities, specialists, personalities, members of non-governmental organizations etc.).

For the program to work, educational establishments can develop partnerships (Article 18 of the methodology) to support activities with institutions that can provide educational services (children's palaces, children's clubs, sports clubs, etc.) and non-governmental organizations, or can enter into partnerships, sponsorship contracts with economic operators.

Funding of the SDS program (Article 17 of the methodology) can be achieved: from the budget of the local authorities; from programs funded by European or national funds; from school and extra-curricular activities, donations, sponsorships, financial support of parent associations or nongovernmental organizations etc., in compliance with the legislation in force; funding can be obtained from the state budget for pupils from disadvantaged groups.

One can see that there are "school-by-school" centers supported by foundations; for example the Royal Margareta of Romania Foundation and the Vodafone Romania Foundation through the Rural Investment Strategic Program 2017-2018 support 310 rural children attending the 8 SDS Centers (National Program "Investment in Rural Environment" 2017-2019, https://www.fpmr.ro/investitie-mediul-rural/). The project "School after school - the first step for school and professional success" (2010-2013) Roma Education Fund Romania Foundation (https:// romaeducationfund.ro/despre-noi-3/cine-suntem-2/) is part of the category of projects with external financing to prevent school dropout, and follows "school after school" programs, remedial education and assisted learning for 2270 primary school pupils in 50 schools (enrollment of Roma children of school age in first class, primary education).

Many SDS programs that have already been implemented have mostly been funded by European funds or by private contributors and, to a small extent, by local public authorities, and the consequence was that they are not implemented in poor areas or in rural areas [5]. It is noted that there are attempts by parents to enroll children in an SDS Program, but the lack of financial resources and dissatisfaction with services are impediments [5]. In 
order to participate in these programs, it is considered necessary to support children from poor families, for equal opportunities and access to education [5].

Article 17 of the methodology/OMECT 5349 allows for financial contributions from parents, but legislation on the functioning of educational establishments prohibits the collection of fees from parents; a solution could be to establish associations of parents with legal personality at school level, to organize SDS Programs [5].

For educational staff, the change from the previous "After School" forms, organized in the premises of the school units, to the SDS Program, led to a decrease in revenues, which generated dissatisfaction.

The payment system is criticized because it does not encourage SDS type programs [5]. According to art. 15 of the methodology/ OMECT 5349, the teaching staff either participate in the SDS Program as an activity included in the didactic norm (maximum 4 hours a week - Article 262 paragraph 1 and Article 263 paragraph 3 of the Law of National Education No. 1/2011), and these hours are not remunerated separately, or they participate as an activity in addition to the activity carried out in the daily 8 hours and 40 hours per week respectively, in which case these hours are paid, according to the law, from the financing sources.

Through these regulations, the payment management of the program's education staff moved from parents 'associations to school, and it was necessary for the amounts to be recorded in school accounts, which overlapped a reduction in income to teachers' dissatisfaction. According to art. 108 of the Law of National Education, state pre-university education establishments can obtain their own income from specific activities, according to the law, from donations, sponsorships or other legally constituted sources.

\section{4. "After school” Program sau „School after school” Program? Replacing "After school" Program with „School After School” Program?}

The SDS program can be organized only within the limits established by the Methodology for organizing this program, with specific steps: organizing the program, establishing the pedagogical team, responsibilities and tasks, approval by the school inspectorate, financing within the limits indicated by the methodology.

For school units that do not support the SDS Program as a complementary school offer, it is not allowed to rent, it is not allowed to 
rent school premises, even available, to individuals or private institutions for the private organization of "School after School" activities; the SDS Program is considered to be only a project that takes place in educational establishments and complies with the methodology (Article 21-22 of the Methodology/OMECT 5349).

There are cases when the "After School" education program is preferred, performing similar activities in private areas outside the school without the specific control of an SDS Program. SDS Program Methodology/ OMECT 5349 prohibits in Article 3 paragraph 9 organizing this program in private units belonging to the didactic or non-teaching staff involved in the program.

The Code of Ethics of 30 August 2018 of the teaching staff in preuniversity education [6], establishes a set of values, principles and norms of conduct according to which the teaching staff must carry out the educational activity (impartiality and objectivity, independence and professional freedom, responsibility, moral and professional integrity etc.). Article 5 of the Code regulates that in the relations with the direct beneficiaries of education, the teaching staff cannot participate in activities that generate corruption, as exemplified by the paid meditations with the direct beneficiaries of the education from the study formations to which it belongs.

\section{Final considerations}

SDS programs are considered as an interdisciplinary and integrated approach to responding to the needs of the child, combining socioeconomic needs with educational needs [5], ie. childcare services (social assistance, child protection, educational services), although this remains only at the level of desideratum and hope.

SDS Programs are considered as integrated support methods aimed at reducing school dropout [7]. These programs help increase school performance and personal development of children [7]. To encourage SDS Programs, funding sources must be identified to support the organization of these programs, with the necessary professional training and appropriate payment of the person involved.

It is noted that there is a fragmentary and unclear legal framework for implementing the SDS Program for disadvantaged groups with the aim of preventing school dropout and there is insufficient financial allocation from the state budget [7]. The establishment of a needs analysis is regulated in the methodology but the criteria are not established. Plus, SDS programs must meet certain minimum quality standards. 
The analysis regarding the functioning of the SDS has shown that there are problems with the lack of human resources and their professional training, the lack of facilities; the number of implemented programs is low; additional involvement of local authorities is required; the methodology is too general; the nationwide expansion of a program for all pupils (funded by the state for disadvantaged and paid by parents for other groups) requires spaces that currently do not exist in many schools; there is a risk that the program will turn into a second school that repeats the formal model; an integrated approach of the program is needed to ensure the quality of the program [7].

\section{References}

[1] Law of National Education no. 1 of 5 January 2011, published in the Official Gazette no 18 of 10 January 2011, as amended by Law no. 102 and 103 of 8 May 2019.

[2] Ministry of National Education. Order no. 5349 of 7 September 2011 on the approval of the Methodology for organizing the "School after School" Program, published in the Official Gazette no. 738 of 20 October 2011, as amended by Order no. 4802 of 31 August 312017 (OMECT 5349).

[3] Inspectoratul Şcolar Județean Iaşi. Strategii de prevenire şi diminuare a abandonului şcolar în județul Iaşi - An şcolar 2017-2018. 2018 [cited 01 mai 2019]. Available online at: https://is.prefectura.mai.gov.ro/wpcontent/uploads/sites/49/2018/03/CP-ISJ-martie-2018.pdf.

[4] Guvernul României. Strategia privind reducerea părăsirii timpurii a şcolii în România. 2015 [cited 01 mai 2019]. Available from https://edu.ro/strategiaprivind-reducerea- $\mathrm{p} \% \mathrm{C} 4 \% 83 \mathrm{r} \% \mathrm{C} 4 \% 83$ sirii-timpurii- $\% \mathrm{C} 8 \% 99$ colii$\% \mathrm{C} 3 \%$ AEn-rom $\% \mathrm{C} 3 \%$ A2nia.

[5] Niculina Petre, Mariana Arnăutu, Bogdan Georoceanu, Beatrice Darie, World Vision Romania. Raportul de cercetare privind nevoia de programe de tip Şcoală dupa Şcoală. Bucureşti. Risoprint. 2013. [cited 01 mai 2019] Available from https://www.worldvision.ro/scoaladupascoala.pdf.

[6] The Code of Ethics of 30 August 2018 of the teaching staff in pre-university education, approved by the Order of the Minister of National Education no. 4.831 of 30 August 2018, published in the Official Gazette no. 844 of 4 October 2018.

[7] Ministry of National Education. Agreement on Technical Assistance Services for Development of the Capacity of Central Public Administration to Conduct Impact Studies, Report on Impact Assessment of Regulations: Content and implementation of a "School after School" National Program. 2016. [cited 01 mai 2019]. Available online at https://sgg.gov.ro/new/wpcontent/uploads/2016/04/RIA-Report-MNE_RO.pdf. 